\title{
An Overview of Environmental Challenges Stifling Sustainable Livelihood in Rural Nigeria
}

\author{
Oluwakemi Abiola Adejumo and Olufemi Adeyemi Owoade \\ Department of Agricultural Education, \\ The College of Education Lanlate, Oyo State, Nigeria
}

\begin{abstract}
General consensus is that Nigeria environment is being degraded but the implications of this on the livelihood of majority of the populace who inhabited the rural areas is usually ignored as they are the voiceless, as voices are only raised when tragedy struck in major cities. Through review of literatures this paper identified environmental problems threatening sustainable rural livelihood in Nigeria to include deforestation, desertification, drought, environmental pollution and climate change. These problems arose from natural and human-made threats and direct and indirect consequences of socio-economic development. This paper argued that listening to the voices of the rural poor is essential in the fight to reduce poverty and resource-scarcity induced conflicts. As the progress whatever the Nigeria nation has made so far has largely been achieved at the detriment of the rural poor. It was reiterated that complete evaluation of environmental degradation should consider the roles marginalization of rural poor, poverty and unsustainable agricultural practices played in undermining achievement of effective environmental protection and management in rural Nigeria. The paper concluded that policies that will bridge increasing gap between rural and urban areas, poor and the rich will go a long way in ensuring sustainability of natural environment.
\end{abstract}

Keywords:- Poverty, Marginalisation, EnvironmentalSensitive, Biodiversity, Natural Environment.

\section{INTRODUCTION}

Nigeria occupies a unique geographic position in Africa and the variability in climate and geographic features endows her with one of the richest biodiversity in the continent. Its diversity of natural ecosystems stretches from the north to the south, and along the eastern border with Cameroon, a montane vegetation. The fact is that from the North to the South Nigeria is blessed and endowed with enormous natural resources and diverse ecosystem.

To the majority of the populace who inhabited the rural areas of Nigeria, natural environment serves as the major supply of food, water, fuel, medicinal plants and a veritable source of income. But today natural and humanmade threats, socio-cultural problems as well as direct and indirect consequences of socio-economic development, particularly deforestation, unsustainable agricultural practices, industrialization, oil exploration, mining and urbanisation, have contributed to the erosion of biodiversity at all levels and further impoverishes the indigenous people who inhabited the rural areas. To this people opening up of previously pristine ecosystems have infringed on their right to good quality life and environment as the resultant environmental degradation leaves deleterious effects on them and the ecosystem causing alteration of habitats, biodiversity loss, pollution and loss of livelihood.

Meanwhile, a major cause of most sustainability issues is overpopulation induced human activities, (Boyce, 1994). As uncontrollable increase in human population put pressure on the natural environment and decimate natural resources base. With Nigeria population projected to be over 400 million by 2050 and growing at the rate of $2.58 \%$, with $52 \%$ of this population living in urban areas (Worldometer, 2020), and increasing rural poverty, Nigeria environment is seriously threatened (NBSAP, 2006).

The potential effects of this situation are disastrous, as it's making environment be under increasing threat from natural disasters and resource scarcity induced-conflicts due to increasing struggle for space, energy, and materials. As more people mean more infrastructure and consumption of food, water, fuel and more emissions of greenhouse gases and waste, resulting in over farming, deforestation, pollution, eutrophication and global warming. On these premises, this paper reviewed major environmental problems in Nigeria and its implications for the indigent who depends on the sustainability of natural environment for survival. The connections between environmental sustainability and sustainable rural livelihood were also examined.

\section{NIGERIA ENVIRONMENTAL CHALLENGES AND IMPLICATIONS ON SUSTAINABLE RURAL LIVELIHOOD}

\footnotetext{
Extent and Implication of Deforestation on Sustainable Rural Livelihood

Forests are essential for human survival and wellbeing as they provide us with food, oxygen, water, fuel wood, medicinal plants, shelter, recreation, and spiritual sustenance. More than 1.6 billion people globally depend to varying degrees on forests for their livelihoods, and approximately 300 million depend on forests directly for their survival, including about 60 million people of indigenous and tribal groups, who are almost wholly dependent on forests for their basic needs (CBD, 2009). However, the biodiversity of forests - the variety of genes, species, and forest ecosystems - underpins these goods and services, and is the basis for long-term forest health and
} 
stability. Therefore, promoting ways to use forest biodiversity in a sustainable way, and with clear social and economic benefits for the poor, is the way to go to make forest to continue support life now and in the future.

CBD (2009) reported that forests harbour two thirds of all terrestrial animal and plant species, and they are the source for over 5,000 commercially-traded products, ranging from pharmaceuticals to timber and clothing. In Nigeria forestry contributes about $3 \%$ of the GDP and accounts for a high proportion of domestic energy, food and medicinal supply of the rural population. In this regard, about 150 indigenous woody plants have been identified as producing food for human and livestock while a lot of other plants are being used for medicinal purposes to cure various diseases (Olagunju, 2015). For these reasons, forests play major role in the rural economy through the harvesting, marketing and utilization of timber and Non-Timber Forest Products (NTFPs). Unfortunately, overexploitation and wanton destruction for socio-economic purposes have led to gradual disappearance of these important functions provided by the forest.

Generally, deforestation is a consequence of overexploitation of natural forest for space, energy, and materials, and has occurred since the dawn of civilisation but reports from various parts of the world indicated that it is now on the increase due to increased socio-economic activities. In Nigeria the main causes of deforestation are population growth and expansion of economic activities such as logging or timber exploitation, farming, oil exploration, industrialisation urbanisation, and bush burning, firewood collection, charcoal production, overgrazing and infrastructures development.

Deforestation has led to acute shortage/scarcity of useful products such as industrial timber, fuel wood, medicinal plants, water, as well as loss of biodiversity which affect genetic diversity of both flora and fauna for continuous improvement of crop and animal species necessary for food security. Again, deforestation is synonymous with the destruction of wildlife habitats (a chief source of animal protein and income for rural poor), and thus, it has drastically reduced wild animal populations, their productivity, and species diversity, while rare species are being threatened with extinction. Deforestation expose the soil to accelerated erosion and runoff which gives rise to flash floods and the development of extensive gullies in various parts of the country, with the South-East being the hardest hit. Also, in the savannah areas, the reduced infiltration rates associated with deforestation adversely affect groundwater recharge and storage. This, have turned some formerly perennial rivers into seasonal or ephemera streams with the rural poor who depends on these rivers and streams for domestic and commercial uses the worst hit. For this reason rural women and children now spent more time searching for water for their families' especially at the peak of dry season (Okunlola and Owoade, 2016).
Global warming resulting in changes in climatic conditions has been traced to continuous disappearance of the forest vegetation. This undeniably affect sustainable livelihood of rural poor. As production-agriculture and fishing, which is a means of livelihood of rural populace, is regarded as a 'major victim' or first casualty of climate change (Owoade and Onifade, 2019). The situation is making hunger and malnutrition inevitable.

The forest resources of Nigeria are under immense human pressure, and major contributory factors to massive deforestation and de-vegetation are exponential increase in population accompanied by intensified industrial activities and the almost total dependence of over 90 per cent of rural population in Nigeria on the forest resources for livelihood and economic survival (NBSAP, 2006). It was reported that about 96 percent of the original 20 percent forest cover has been cleared and only 2 percent of what remains is undisturbed (Onyeanusi and Otegbeye, 2012). This has resulted in massive loss of the very rich and diverse forest flora and fauna, including indigenous tree species. The implication of all these, is that the remaining forest resources in Nigeria will likely disappear soonest than expected if the current rate of forest depletion continues unabated and necessary actions taken to extend the extent of forest wealth. And this portends grievous danger for the rural populace who has fewer alternatives for survival and sustainable livelihood.

\section{$>$ Extent and Implication of Drought and Desertification on Sustainable Rural Livelihood}

Desertification and drought have become a major developmental and environmental problem in many parts of Nigeria, particularly in the region north of latitude $10^{\circ} \mathrm{N}$, as large parts of the savanna are being ravaged by maninduced desertification, causing ecosystem impoverishment and biodiversity loss. It was estimated that between 50 and 75 percent of north-east and north-west states are being affected by desertification and severe dry spells (Olagunju, 2015). On a final analysis, it is estimated that the country is currently loosing 351,000 hectares of its landmass to desert-like conditions annually, and such conditions are estimated to be advancing southwards at the rate of about 0.6km per year (Folaji, 2007).

Generally, desertification and drought are associated with reduction in the capacity of the land to perform basic functions that affects its economic value needed by human. Drought and desertification processes integrate climatic elements with human activities in transforming productive land, into an ecological impoverished area generally refers to as desert. Drought and desertification cause degradation of once a fertile land through long term changes in the soil, climate and biota, which results in desert-like conditions. Olagunju (2015) identified climatic variability and anthropogenic activities such as deforestation, extensive cultivation, overgrazing, cultivation of marginal land, bush burning, fuel wood extraction, faulty irrigation system and urbanization as major causes of desertification in Nigeria. 
Effects of persistent droughts may result in failure of crops and death livestock, which may eventually bring about famine and further impoverish the rural poor who majorly depend on farming and other related activities for sustenance. Also, drought and desertification-induced changes in population dynamics may include increased migration from rural areas into the urban centers, resource depleted into 'perceived' resource abundance areas (Amzat, 2013). As people have to leave the areas they grew up and abandon their homes as their means of livelihood is being eroded and there are fewer alternatives. This leads to greater pressure on the existing urban infrastructure, and subsequent social conflicts in the affected areas as being presently witnessed in the escalation of farmers-herdsmen conflicts all over the country.

\section{$>$ Extent and Implication of Pollution on Sustainable Rural Livelihood}

Pollution is the act of introducing harmful or unpleasant substances that make the environment dirty or no longer pure (Jande, 2005). Eneh and Agbazue (2011) observed that environmental pollution in Nigeria is much greater in magnitude today than in previous decades. This is as a result of the high rate of population growth and urbanization, industrialization and oil exploration, modernization of agriculture, especially in the growing use of agrochemicals, mechanisation and fossil fuel, the introduction of new technologies and consumer products, and the ineffectiveness of the institutional, logistical and policy arrangements put in place over the years to tackle the menace (Nwokoro and Chima, 2017).

Globally, man-made pollutants arising from combustion, industrialization, construction work of various kind, mining, agriculture and warfare are increasingly significant in the air pollution, and have negative effect on man's survival in the environment through its influence on health, food security, water supply and livelihood (Nwafor, 2006). The presence of one or more contaminants in the atmosphere caused pneumonia, whooping cough, measles, carcinogenicity, pulmonary tuberculosis and cerebrospinal meningitis (Nwachukwu and Ugwuanyi, 2010).

Globally, one of the leading sources of air pollution is motor vehicle emissions (Van Loon and Duffy, 2000). Also of importance is agricultural air pollution which comes from contemporary practices, which include bush burning as well as spraying of pesticides and herbicides (Eneh, 2011b). These activities raised carbon dioxide level in the atmosphere. While long-term rising levels of atmospheric carbon dioxide has the potential to cause climate change and slight, but critical, increases in the acidity of ocean water, with possible adverse effect on marine ecosystems (Sharma, 2002). This affects the means of livelihood of indigent who depends on this ecosystem for sustenance.

In Nigeria, gas flaring is a dangerous activity, as gas pollutants contain over 250 toxins that are harmful, poisonous and unfriendly to the natural ecosystems and human habitats (Raimi et al., 2013). Gas flaring manifested in the forms of gas leakages directly into the atmosphere causing fire incidents and heating up the atmospheric air. This unwholesome activity destroys flora and fauna living in the affected areas and communities, and destroyed the means of livelihood of indigenous people who depends on these ecosystems for sustenance (Zabbey, 2004). The atmospheric contaminants associated with gas flaring acidify the soil, depleting soil nutrient and the nutritional value of crop within such vicinity is reduced (Etuonovbe, 2009). This situation rendered farmlands useless, production of crops and fishing in affected areas impossible.

Water pollution, this is another important pollution that affects the quality of water available for human, animals and plants. Water pollution causes approximately 14,000 deaths per day, mostly due to contamination of drinking water by untreated sewage in developing countries (Kallman, 2008). Efe (2006) identified contaminants that make water unsuitable include salts, suspended solids, chloride, nitrate, arsenic, heavy metals, pathogenic organisms, and a wide variety of organic chemicals including pesticides, petroleum compounds, and solvents. Water hyacinth is an invader on water by altering the quality of water (Tobias et al., 2019). The dissolved oxygen required by living organisms is reduced in areas with water hyacinth (CDBW, 2017).

Since water is essential for sustaining life, rural women and children bore the brunt of finding water. The time cost for water collection has been estimated at 40 billion hours per year in sub-Saharan Africa (Lenton et al., 2005). The burden of fetching water affects participation of girls and women in school, employment and other income generating activities (Lowe et al., 2019). Travelling long distance for water increases the incidence of rape and abduction of girls, while lack of adequate access to safe water and sanitation causes maternal and child mortality (Eneh, 2011a). Water polluted with oil spillage also affects aquatic animals meant for human consumption, as fish contaminated by oil causes sickness among the people and further economic ruin as fish stocks decline (Etuonovbe, 2009). This affected the survival of rural fishing community who inhabited the coastal areas and depends on fishing for food and income.

\section{Extent and Implication of Climate change on Sustainable Rural Livelihood}

General consensus is that considerable changes have taken place in the composition of atmospheric gases due to natural processes and human activities, such as increasing energy consumption, industrialization, intensive agricultural practices, deforestation, urban and rural development among others. These changes have led to rise in global temperature and high spatial and temporal variability (United Nation Framework Convention on Climate Change (UNFCCC), 1992).

Bello (2010) identified rise in temperature and drought as evidences of climate change. Other evidences include: increase in annual rainfall during wet season resulting in flooding; shorter rainy season and longer dry 
season; increasing cases of dry spells and drought; unpredictability of rainfall; change in the distribution of rainfall in wet season; excessive dryness during dry season and; increasing temperature in wet and dry seasons likewise the harmattan period (Audu et al., 2013). The devastation accompanying such extremes weather events has mainly impacted on agriculture, ecosystem, water resources and general environment. The effect also includes fiercer weather, increased frequency and intensity of storms, floods, hurricanes, droughts, increased frequency of fires, poverty, malnutrition and series of health and socioeconomic consequences (Eze et al., 2012).

In Nigeria, climate change has implications either directly or indirectly on agriculture in number of ways as agriculture is still being majorly practiced by the dictate of weather. Specifically, incidences of climate change on agriculture include changes in soil moisture, soil quality, crop resilience, timing/length of growing seasons, yield of crops and animals, atmospheric temperatures, weed insurgence, flooding, unprecedented droughts, sea level rises and many more (Ozor and Nnaji, 2011). All these combined together to affect farmers productivity, food security and sustainability and livelihood of small holder rural farmers who depends solely on farming and related economic activities as source of income.

Mashi (2020) pointed out that projected impact of climate change on agricultural yields between 2003 and the 2080s reveals that Nigeria lies between -5 and -15 per cent expected production level. The author also pointed out observed changes in rainfall distribution patterns in Nigeria from 1951- 2012 as shown in the rainfall anomaly chart with corresponding periods of occurrence of extreme rainfall events drought and floods. All these expressed grave concern that Nigeria is strongly predisposed to severe negative impacts of climate change due to its fragile economy, weak resilience and low adaptive capacity as much of the economy is dependent on climate-sensitive resources and economic activities (Owoade and Onifade, 2019).

With Nigerian agriculture being majorly rain fed, food production system will be adversely affected by the variability in timing and amount of rainfall, frequent outbreaks of crop pests and diseases and heat stress. Mostly affected are women and men living in rural areas depending on agriculture-based livelihood systems that were already vulnerable, particularly those that typically face environmental shocks and had few alternatives face substantial impacts (Owoade and Onifade, 2019). For these reasons, climate change poses significant threats to agricultural production and trade, and consequently increases the risks of malnutrition and extreme hunger especially for rural people.

\section{> Nexus of Environmental Sustainability and Sustainable Rural Livelihood}

Nigeria's rural dwellers constitute $53 \%$ of the country's total population (World Bank, 2015), and the bulk of Nigeria's natural resources, food and fibre supply come from the rural areas, which has long contributed significantly to the country's Gross Domestic Product (GDP). Unfortunately, despite the abundance of resources, poverty is a common phenomenon in Nigeria's rural areas, as most rural households fall below the USD 1.90/day poverty line and over 70 percent defined as "very poor," based on a measure of daily per capita expenditures (WorldFish, 2018). Succinctly, Nigeria rural areas have peculiar features of low income, low productivity, and high degree of unemployment, high population rate, poor technological growth, low infrastructures, high illiteracy rate and malnutrition (Nwankwo \& Okeke, 2017).

Although, rural areas relate to geographical locations where industry and infrastructure are not developed and farming and related economic activities are the dominant occupation but it inhabited majority of the poor and marginalized (Madeley, 2008). A staggering 75 per cent of the world poor who live in rural areas depend on the environmental-sensitive resources for provision of basic needs (fuel, shelter, water, medicine and food) and survival (Convention on Biological Diversity (CBD), 2009). Interestingly, policies and resources continue to be biased in favour of urban development with detrimental effects for both rural and urban populations. These situations make the poor state of most rural economies very devastating and pathetic.

Nigeria has three main ecological zones: savanna, tropical forests, and coastal wetlands. These environmental regions greatly affect the cultures of the indigenous people who live there in terms of occupation and mode of life (Akinwale, 2010). For instance, open grasslands of the savanna make cereal farming and herding a way of life for the nomadic Hausa-Fulani found in the north (Fabusoro et al., 2007). While the tropical forests in the south provide opportunities of sustainable livelihood through agriculture and exploitation of numerous forest resources and wetland that extends along the coast of southern Nigeria for the sedentary indigenous people found in the rural areas of southern Nigeria. In nut shell, the indigenous people are products of the environment while their understanding of the environment affects their sustenance (Akinwale, 2010).

In spite of Nigeria's oil resources, agriculture remains the base of the country's economy, and 80 percent of the rural households working population engage in farming and other related activities as their primary income activity (Adedokun et al., 2005). Today increasing adoption of mechanization, agrochemicals, improved crop and animal husbandry by small holder rural farmers have had many positive effects on their well-being and reduced many risks in farming, but there have also been significant costs. Prominent among these are topsoil depletion, groundwater contamination, eutrophication, increased production of greenhouse gases, desertification/deforestation, increased 
flooding, the decline of family farms, continued neglect of the living and working conditions for farm labourers, increasing costs of production, and the disintegration of economic and social conditions in rural communities (Adedokun et al., 2005) These situations further degraded natural environment and destabilized sustainable livelihood in most rural communities. Making indigenous people leave the environment they grew up in because potential for sustainable livelihood are fast disappearing.

In the main time, large scale environmental degradation is largely a rural phenomenon but many of its drivers can be traced to the consumption demand of swelling urban population. Nwokoro and Chima (2017) posited that rural poverty and marginalisation increase the depletion of environmental resources as rural dwellers struggling to survive cannot afford to practice efficient resource conservation and utilisation methods in their daily survival strategies. Thus, environmental sustainability and eradication of extreme poverty are intimately connected, and require a coordinated response, as there are relationships between natural environment and rural livelihood on one hand and environmental degradation and rural poverty on the other. Therefore, proper understanding of the indigenous people interactions with their environment will go a long way in proffering lasting solution to environmental degradation and this include protecting their means of livelihood.

Therefore, complete evaluation of environmental degradation should consider the roles other factors such as poverty, population increase, marginalization of rural poor, increasing gap between poor and rich, rural and urban areas, natural and built environment and inefficient resource use in agriculture have played in limiting achievement of effective environmental protection and management in poverty prone communities. Specifically, needs of vulnerable who depends solely on the natural environment for survival should be taken into considerations, efforts should be concentrated at taking the poor inhabiting the rural areas out of subsistence and bridge the increasing gap between them and urban communities.

\section{CONCLUSION}

Rural households unsustainable agricultural practices and further exploration of the natural environment, which they considered as free gift of nature, to eke out living and help themselves out further impoverishes them and degraded natural environment. As people that are poor can neither imbibe value of respect nor adopt responsible environmental behaviour in their struggle for survival.

To this effect, this paper reiterated formulation and pursue of policies that will support and encourage rural dwellers to get out of subsistence, practice sustainable livelihood and reduce rural poverty will help to reduce pressure on natural environment, stem rural-urban drifts and ensure environmental conservation and sustainability. Although, promoting environmental responsible behavior and value of respect may promote harmonious relationship between human and nature but to people struggling to survive it is just rhetoric. The paper then posited that formulation and implementation of policies that would support aggressive rural infrastructure development, land reforms and recognizing indigenous people's resource control right, and adding land value taxes would address inequality and build the trust of rural poor at supporting government policies aim at conservation and sustainable management of Nigeria natural environment.

\section{REFERENCES}

[1]. Adedokun, O.A., Akanni, K.O., Adedoyin, S.F. \& Marafa, A.S. (2005) Effects of farming practices on the environment: need for awareness among farmers in rural areas of Nigeria. Pp 126-129. In: Okonkwo, E., Adekunle, V. and Adeduntan, S. (Eds.). Environmental sustainability and conservation in Nigeria.

[2]. Akinwale, A. A. (2010) Livelihoods and environmental challenges in coastal communities of

Nigeria. Journal of Sustainable Development in Africa, 12(8): 79-88.

[3]. Amzat, A. (2013) Menace of herdsmen: Like Sudan like Nigeria. The Guardian: Nigeria. Published Saturday $27^{\text {th }}$ April, 2013.

[4]. Audu, E. B, Audu, H. O, Binbol, N. L. \& Gana, J. N. (2013) Climate change and its implication on agriculture in Nigeria. Abuja Journal of Geography and Development, 3(2):8-19.

[5]. Bello, N.J. (2010) Climate Change: Implications for food production and security in Nigeria. In: Climate Change Impacts and Adaptation: Developmental Issues. A Special Book on Climate Change. Published by Nigerian Meteorological Society. Pp 3 - 5 .

[6]. Convention on Biological Diversity (CBD) (2009). A Good Practice Guide: Sustainable Forest Management, Biodiversity and Livelihood: International Union for Conservation of Nature (IUCN). Pp 3-5. https://www.cbd.int/development/doc/cbd-goodpractice-guide-forestry-booklet-web-en.pdf

[7]. CDBW (2017) Floating aquatic vegetation control program water hyacinth spongeplant and water primrose 2016 annual monitoring report. Jan 31, 2017. Sacamento CA. 2016. Retrieved February 17, 2020 from http://www.dbw.ca.gov/pages/28702/files/FAV\%20\%2 02016\%20Annual\%20Monitorin\%20Report.pdf

[8]. Efe, S.I. (2006) Quality of rainwater harvesting for rural communities of Delta State, Nigeria. Environmentalist, 26:175-181.

[9]. Eneh, O.C. (2011a) Effects of water and sanitation crisis on infants and under-five children in Africa. Journal of Environmental Science and Technology, 4: 103-111. 
[10]. Eneh, O. C. (2011b) Enhancing Africa's environmental management: Integrated pest management for the minimization of agricultural pesticides pollution. Journal of Environmental Science and Technology, 5(6): 521-529.

[11]. Eneh, O.C \& Agbazue, V. C. (2011) Protection of Nigeria's Environment: A Critical Policy Review. Journal of Environmental Science and Technology, 4: 490-497.

[12]. Etuonovbe, A. K. (2009) The Devastating Effects of Environmental Degradation - A Case Study of the Niger Delta Region of Nigeria. FIG Working Week 2009 Surveyors Key Role in Accelerated Development Eilat, Israel, 3-8 May, 2009.

[13]. Eze, U. F., Ikeogu, C., Iwuh, C. F. \& Nwakama C. I. (2012) Review of potential applications of GIS and welfare forecasting to challenge climate hazards in developing countries: Nigeria as a case study. International Journal of Development Digest, Mid-year special edition, 15(1): 60-77.

[14]. Fabusoro, E., Matsumoto, T. \& Taeb, M. (2007) Land rights regimes in southwest Nigeria: Implications for land access and livelihoods security of settled Fulani and pastoralists. Land Degradation and Development, 19(1): 91-103.

[15]. Folaji , M.B. (2007) Combating Environmental Degradation in Nigeria: A Case Study of Desertification in Kano State. A College paper submitted to the Armed Forces Command and Staff College Jaji Food and Agriculture Organisation (FAO) (2006). Retrieved June 8, 2017 from https://academicjournals.org/journal/JENE/articlefull-text-pdf/4505E2154369

[16]. Jande, G.G. (2005) Legal Mechanisms for the control of Pollution on the high seas. African Journal of Environmental Law and Development Studies, 1(1): 1 $-13$.

[17]. Kallman, M. (2008) Air pollution's causes, consequences and solutions. World Resources Institute: August 2008 Monthly Update. http://earthtrends.wri.org/updates/node/325

[18]. Lenton, R., Wright, A.M. \& Lewis, K. (2005) Health, dignity, and development: what will it take? UN Millenium Project Task Force on Water and Sanitation. New York and Stockholm: United Nations and Stockholm International Water Institute.

[19]. Lowe, C., Ludi, E., Le Sève, M.D. \& Tsui, J. (2019) Linking social protection and water security to empower women and girls. Working Paper 567. Retrieved July 13, 2020 from https://www.odi.org/sites/odi.org.uk/files/resourcedoc uments/linking_social_protection_to_wate_security_fi nal_digital.pdf

[20]. Madeley, J. (2008) Farmers who live on the edge; Development Issue 40. Pp. 28. DFID UK.

[21]. Mashi, S. A. (2020) NIRSAL, NiMET collaborate to stem risks in agriculture. EnviroNews Nigeria.

Retrieved March 2, 2020 from http://www.environewsnigeria.com/nirsal-nimetcollaborate-to-stem-risks-in-agriculturel
[22]. National Biodiversity Stratetegy and Action Plan (NBSAP) (2016) Federal Republic of Nigeria. Retrieved July 28, 2020 from https://www.cbd.int/doc/world/ng/ng-nbsap-v2-en.pdf

[23]. Nwafor, J.C. (2006) Environmental Impact Assessment for Sustainable Development: The Nigerian Perspective. Environment and Development Policy Centre for Africa, Enugu.

[24]. Nwankwo, F.O. \& Okeke, C.S. (2017) Rural entrepreneurship and rural development in Nigeria. Africa's Public Service Delivery and Performance Review, 5(1): 152.

[25]. Nwachukwu, A.N. \& Ugwuanyi, J.U. (2010) Air pollution and its possible health effects on rural dwellers in Rivers State, Nigeria. Afr. J. Phys., 3: $217-$ 240.

[26]. Nwokoro, C. V. \& Chima, F. O. (2017) Impact of environmental degradation on agricultural production and poverty in rural Nigeria. American International Journal of Contemporary Research, 7: 2.

[27]. Okunlola, O. O. \& Owoade, O. A. (2016) Evaluation of activities of women-in-agriculture in Ibarapa East Local Government Area of Oyo State, Nigeria. The Pacesetter, 20: 2. Retrieved from May 5, 2019 from http://randp.eacoed.edu.ng/publication

[28]. Olagunju, T. E. (2015) Drought, desertification and the Nigerian environment: A review. Journal of Ecology and the Natural Environment, 7(7): 196-209.

[29]. Owoade, O. A. \& Onifade, A. O. (2019) Climate change awareness and adaptation strategies used by farmers in Ibarapa North Local Government Area of Oyo State. A proceeding of agriculture, management and technology conference, held at Oyo State College of Agriculture and Technology, Igboora, October 14-17, 2019. Pp14-17

[30]. Onyeanusi, A.E. \& Otegbeye, G.O. (2012) The impact of deforestation on soil erosion and on the Socioeconomic life of Nigerians. Sustainable Environmental Management in Nigeria, Book Builders publisher, Nigeria. Pp. 315-331.

[31]. Ozor, N. \& Nnaji C. (2011) The role of extension in agricultural adaptation to climate change in Enugu State. Nigeria Journal of Agricultural Extension and Rural Development, 3(3): $\quad 42-$ 50.

[32]. Raimi, L., Towobola, W. L. \& Madueke, L.I. (2013) Redressing the Energy Challenge of Gas Flaringin Nigeria: The MEEs Approach. Journal of Sustainable Development Studies, 2(2): 242-257.

[33]. Sharma, B.K. (2002) Engineering Chemistry. Krishna Prakashan Media Pvt. Ltd., Meerut-India.

[34]. Tobias, V.D., Conrad, J.L., Mahardja, B. \& Khanna, S. (2019) Impacts of water hyacinth treatment on water quality in tidal estuarine environment. Biological invasions, 21: 3479-3490.

[35]. UN Framework Convention on Climate Change (UNFCCC). (1992). Retrieved Sept. 25, 2015 fromhttps://treaties.un.org/doc/Treaties/1994/03/1 9940321\%200456\%20AM/Ch_XXVII_07ppdf. 
[36]. Van-Loon, G.W. \& Duffy, S.J. (2000) Environmental Chemistry: A Global Perspective. Oxford University Press, Oxford.

[37]. World Bank/IFC/MIGA (2011) Growth and productivity in agriculture and agribusiness: evaluative lessons from World Bank Group experience: Independent Evaluation Group Publication. World Bank (2015) World development indicators: rural environment and land use: World Bank Group, Washington, DC. Retrieved May 17, 2019 from http://www.wdi.worlbank.org/table/3.1

[38]. World Bank (2018) Nigeria-Rural population. Trading Economics.Retrieved March 17, 2020 from https://tradingeconomics.com/nigeria/ruralpopulation-percent-of-total-population- $\quad w b$ data.html

[39]. WorldFish (2018) WorldFish Nigeria Strategy: 20182022. Penang, Malaysia: WorldFish. Strategy. Retrieved September18, 2019 from http://pubs.iclarm.net/resource_centre/2018-09.pdfs

[40]. Worldometer (2020). Nigeria population 1950-2020. Retrieved on 16/07/2020

from: www.worldometer.info

[41]. Zabbey, N. (2004) Impacts of Extractive Industries on the Biodiversity of the Niger Delta Region Nigeria. Presentation at a 3-Day National Workshop on Coastal and Marine Biodiversity Management Held in Pyramid Hotel, Calabar, CrossRiver State, between 7- 9 September, 2004 Jointly Organised by Akpabuyo Bakassi Green Movement (Agremo), Calabar and Special Unit for Technical Co-Operation among Development Countries of UNDP (SU/TCDC/UNDP). 